\title{
3. Walne Zebranie Stowarzyszenia Biblistów Polskich i 44. Sympozjum Biblistów Polskich (Kalisz, 19-21 września 2006)
}

Tegoroczne Sympozjum Biblistów Polskich odbyło się w Kaliszu. Gospodarz miejsca bp dr Stanisław Napierała powitał serdecznie zebranych podczas kolacji, przed którą odbyło się zebranie zarządu Stowarzyszenia Biblistów Polskich, a po niej o godz. 19.00 walne zebranie Stowarzyszenia. Przewodniczący ks. prof. Waldemar Chrostowski wspomniał na nim zmarłych członków, przede wszystkim o. prof. Augustyna Jankowskiego OSB i omówił działanie stowarzyszenia w minionym roku. Podziękował biskupowi prof. Zbigniewowi Kiernikowskiemu za finansowe wspieranie prac towarzystwa, zwłaszcza wydania przez Wydawnictwo Uniwersytetu Kardynała Stefana Wyszyńskiego dzieła zbiorowego Joannes Paulus II - in memoriam. Księga Pamiątkowa Stowarzyszenia Biblistów Polskich ku czci Ojca Świętego Jana Pawła II.

Skarbnik ks. prof. Tomasz Jelonek złożył sprawozdanie dotyczące majątku SBP, które w głosowaniu zostało przyjęte. Nadano członkostwo honorowe STB ks. prof. Józefowi Kudasiewiczowi, który w bieżącym roku kończy 80 lat życia. Przez głosowanie przyjęto też regulamin członkostwa zwyczajnego SBP. Dyskutowano nad projektami członkostwa stowarzyszonego i regulaminu wyboru zarządu.

Sympozjum rozpoczęło się mszą świętą 20 września o 7.30 w kaplicy seminaryjnej pod przewodnictwem metropolity poznańskiego abpa dra Stanisława Gądeckiego.

Podczas I sesji ks. prof. Waldemar Chrostowski wygłosił referat Kościót i Biblia omawiając wartość i ograniczenia metody historyczno-krytycznej; ks. dr Waldemar Linke CP w komunikacie przedstawił problem natchnienia Księgi Tobiasza. Po dyskusji na temat metod i sposobów podejścia do Biblii w nauce i duszpasterstwie była krótka przerwa na kawę. W czasie tej i następnych przerw można było nabywać nowe, interesujące pozycje z zakresu nauk biblijnych i duszpasterstwa biblijnego.

II sesja nosiła tytuł Dzień słowacki. Złożyły się na nią trzy wystąpienia: ks. doc. Pavola Farkaša Wiedza biblijna w Słowacji do 1989 roku; ks. dr 
Františka Trstenskŷ'ego Wiedza biblijna w Słowacji po 1989 roku (z wykorzystaniem pomocy wizualnych) i ks. prof. Antona Tyrola Działalność Katolickiego Dzieła Biblijnego w Stowacji. Po dyskusji nastąpiła promocja Księgi Pamiątkowej Stowarzyszenia Biblistów Polskich ku czci Ojca Świętego Jana Pawta II, wręczenie księgi pamiątkowej „Bóg jest miłością” $(1 \mathrm{~J}$ 4, 16). Studia dla Księdza Profesora Józefa Kudasiewicza w 80. rocznicę urodzin, red. W. Chrostowski (Rozprawy i Studia Biblijne 25), komunikaty wydawnicze, wspólna fotografia pamiątkowa i obiad. Po nim była możliwość zwiedzenia najstarszego polskiego miasta, zwłaszcza sanktuarium św. Józefa z kaplicą męczenników II wojny światowej, które przedstawił zebranym jego kustosz.

III sesja rozpoczęła się spotkaniami w grupach roboczych: Cykl o ustanowieniu monarchii w Izraela (1 Sm 8-12) - prowadził ks. dr Dariusz Dziadosz; Egzegeza narracyjna: wprowadzenie w metodę i przykład zastosowania - prowadził ks. dr hab. Zdzisław Pawłowski; Piśmiennictwo targumiczne. Znaczenie stownika internetowego „Comprehensive Aramaic Dictionary” - prowadził ks. dr Jerzy Woźniak CM; Tło Biblii. Bajki Ezopowe a Nowy Testament - prowadził prof. M. Wojciechowski.

Po mniej więcej godzinnym przedstawieniu problemów i dyskusji wszyscy zebrali się $\mathrm{w}$ auli i przedstawiono sprawozdania $\mathrm{z}$ pracy $\mathrm{w}$ grupach. Okazała się ona bardzo owocna i wyrażono życzenie, by w przyszłości często stosować tę formę obrad.

Wieczorem odbyło się spotkanie towarzyskie w refektarzu seminarium.

Ostatni dzień rozpoczął się mszą świętą pod przewodnictwem biskupa kaliskiego dra Stanisława Napierały.

Na IV sesję złożyły się: referat dr Zofii Włodarczyk Ogród biblijny jako forma ewangelizacji wzbogacony zdjęciami istniejących na całym świecie ogrodów, oraz komunikat wykładającego w Rzymie ks. dra Andrzeja Gieniusza CR 7. wersja programu Bible Works. Prelegent należący do jego autorów w ciekawy i kompetentny sposób demonstrował możliwości, jakie otwiera on przed swymi użytkownikami.

Ostatnia sesja zawierała komunikaty dotyczące Starego Testamentu, okresu międzytestamentalnego i ostatniej księgi Nowego Testamentu - Apokalipsy: ks. dr Wojciech Pikor: Izajaszowy „Stuga Jahwe” (Iz 42,1-9) a Nowe Przymierze. Analiza kontekstualna; dr Anna Kuśmirek: Antropomorfizmy w Targumach do Pięcioksięgu; ks. dr Dariusz Kotecki:Duch Święty w zgromadzeniu liturgicznym w świetle Apokalipsy św. Jana. Po krótkiej dyskusji dotyczącej komunikatów przewodniczący sekcji ks. prof. Waldemar Chrostowski otworzył dyskusję podsumowującą, w której wypowiadano się na temat wartości wspólnych spotkań, wymiany poglądów, doświadczeń, przedstawiania różnorodnych metod prowadzących do wspólnego celu: lepszego odczytania i głębszego 
poznania sensu świętych tekstów i sposobów przekazania ich studentom i wiernym. Jako miejsce następnego spotkania w 2007 roku podano Pelplin. Po obiedzie uczestnicy sympozjum opuścili gościnny Kalisz.

W sympozjum wzięło udział około 150 osób. W kilku sesjach uczestniczył metropolita wrocławski abp prof. Marian Gołębiewski, na jednej z sesji był biskup pomocniczy dr Teofil Wilski. Oprócz księży uczestniczyły w nim siostry zakonne oraz świeccy bibliści. Byli też przedstawiciele innych wspólnot chrześcijańskich. Dało to okazję zarówno do pogłębienia wiedzy, jak też wzajemnego poznania i nawiązania bliższych kontaktów owocujących w późniejszej pracy.

Kraków Tyniec

TOMASZ MARIA DĄBEK OSB 


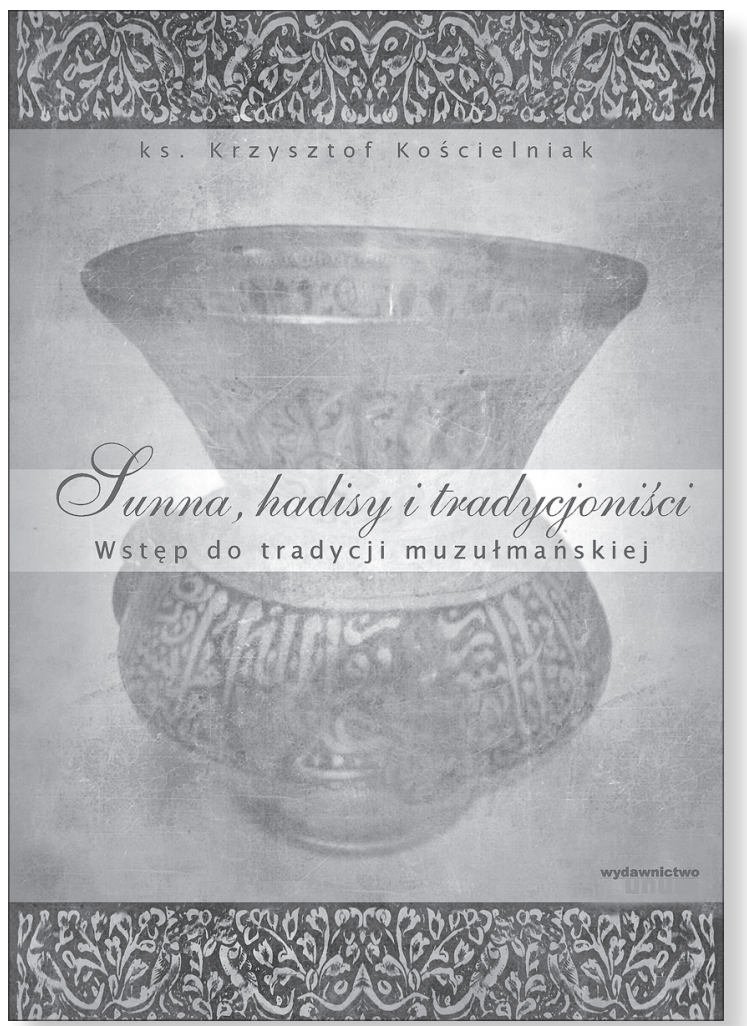

\title{
NOWOŚć!
}

ks. Krzysztof Kościelniak

\section{Sunna, hadisy i tradycjoniści}

\author{
WSTEP DO TRADYCJI \\ MUZUUMAŃSKIEJ
}

141 stron $\cdot$ format $14,5 \times 20,5 \mathrm{~mm}$ oprawa broszurowa $\cdot$ cena 19 zł

Hadisy są drugim po Koranie spisanym źródłem teologii muzułmańskiej. Zawierają one wypowiedzi Mahometa, opowiadania, relacje czy przypowieści na temat jego życia. Hadisy są „nośnikami” tradycji muzułmańskiej i mają zarówno charakter religijny, jak również prawny i etyczny. Tworzą one tzw. sunnę, czyli „ścieżkę Mahometa”, którą winna kierować się cała umma - „społeczność muzułmańska”.

Islam sunnicki przywiązuje do tradycji tak wielką wagę, że o sunnitach zwykło mówić się jako o „ludziach tradycji i wspólnoty". Zdaniem sunnitów każdy muzułmanin powinien poprawiać całe swoje życie w świetle sunny nawet w najmniejszych detalach, aby uchronić się przed jakimikolwiek nagannymi innowacjami religijnymi. W konsekwencji tradycja muzułmańska z jednej strony przedstawia i wciela w praktykę przepisy koraniczne, z drugiej strony zaś sama w sobie stanowi źródło dogmatów i moralności. Już w VIII wieku Koran i sunna zostały zrównane co do ważności, a specjaliści od hadisów szybko uznali siebie za znawców prawa, teologów, egzegetów i specjalistów czytania Koranu.

Książka Sunna, hadisy i tradycjoniści wprowadza czytelnika w świat tradycji islamskiej, omawia aspekty etymologiczne i historię sunny Proroka oraz znaczenie hadisów w muzułmańskich klasycznych szkołach teologiczno-prawniczych, prezentuje islamskie metody weryfikacji tradycji, ukazuje różne aspekty prowadzonej od lat dyskusji naukowej wśród orientalistów i teologów muzułmańskich na temat prawdziwości hadisów.

Publikacja została zainspirowana zachodnimi introdukcjami do sunny i jest próbą wypełnienia luki na temat tradycji muzułmańskiej w literaturze polskiej. Intencją autora jest, aby niniejsza praca stała się podręcznym wprowadzeniem zawierającym podstawowe zagadnienia związane z tradycją muzułmańską wraz z podstawową bibliografią.

\section{Zamówienia}

Wydawnictwo UNUM · ul. Kanonicza 3 · 31-002 Kraków tel. (12) $4225690 \cdot$ e-mail: unum@ptt.net.pl

Koszt przesyłki ponosi wydawnictwo. 